\title{
PELATIHAN PEMBUATAN NATA DE COCO DARI LIMBAH AIR KELAPA DI DESA DUNU KECAMATAN MONANO KABUPATEN GORONTALO UTARA
}

\section{Training Of Making Nata De Coco From Coconut Water Waste In Dunu Village, Monano Subdistrict, North Gorontalo District}

\author{
Trifandi Lasalewo ${ }^{1)}$, Herinda Mardin ${ }^{2)}$ \\ ${ }^{1}$ Program Studi Teknik Industri, Fakultas Teknik Universitas Negeri Gorontalo \\ ${ }^{2}$ Program Studi Pendidikan Biologi, Jurusan Biologi FMIPA Universitas Negeri Gorontalo \\ Email: trifandilasalewo@ung.ac.id ${ }^{1)}$ \\ Email: herindamardin@ung.ac.id ${ }^{2)}$
}

\begin{abstract}
ABSTRAK
Tanaman kelapa memiliki beragam manfaat mulai dari buah, batang, daun dan air kelapa. Buah kelapa dimanfaatkan oleh masyarakat di desa Dunu kecamatan Monano Kabupaten Gorontalo Utara menjadi kopra. Dalam proses pembuatan kopra, air kelapa di desa Dunu kurang dimanfaatkan secara maksimal sehingga menjadi limbah. Limbah air kelapa dapat digunakan dalam pembuatan nata de coco dengan menggunakan mikroorganisme Acetobacter xylinum. Untuk itu, dengan melimpahnya air kelapa di desa Dunu, sehingga dilakukan pelatihan pembuatan nata de coco. Tujuan dari kegiatan pelatihan ini diharapkan dapat memberikan informasi, skill dan pengetahuan kepada masyarakat desa Dunu dalam memanfaatkan limbah air kelapa menjadi produk nata de coco sehingga mampu meningkatkan pendapatan ekonomi masyarakat juga mampu menjaga kebersihan lingkungan sekitar dari limbah air kelapa. Pelatihan pembuatan nata de coco dari limbah air kelapa di desa Dunu, Kecamatan Monano Kabupaten Gorontalo Utara ini dilaksanakan pada hari Minggu tanggal 20 September 2020 dengan melibatkan 65 orang peserta bertempat di aula kantor desa Dunu. Metode pelaksanaan kegiatan ini adalah pelatihan langsung dan praktik. Hasil dari kegiatan pelatihan pembuatan nata de coco dari limbah air kelapa ini adalah peserta mendapatkan informasi, skill dan pengetahuan mengenai cara pembuatan nata de coco dari air kelapa. Selain itu, peserta juga mendapat pengetahuan dan skill mengenai cara pembibitan starter nata de coco dari mikroorganisme bakteri Acetobacter xylinum.
\end{abstract}

\section{Kata kunci: Pelatihan, Nata De Coco, Air Kelapa, Acetobacter xylinum}

\section{ABSTRACT}

Coconut plants have plenty of benefits ranging from its fruit, stems, leaves and coconut water. Coconut fruit is used by the community in Dunu village, Monano district, North Gorontalo district to become copra. In the copra-making process, coconut water in Dunu village is not fully utilized so that it becomes waste. Coconut water waste can be used in making nata de coco by using the microorganism Acetobacter Xylinum. For this reason, the abundance of coconut water in Dunu Village led to training in making nata de coco. The purpose of this training activity is to provide information, skills and knowledge to the people of Dunu village in utilizing coconut water waste into nata de coco products hence it can increase the economic income of the community as well as being able to maintain the cleanliness of the surrounding environment from coconut water waste. The training on making nata de coco from coconut water waste in Dunu village, Monano District, North Gorontalo Regency was held on Sunday, September 20, 2020, involving 65 participants at the Dunu village office hall. The method of 
implementing this activity is practical and on the spot training. The result of the training on making nata de coco from coconut water waste was that the participants received information, skills and knowledge on how to make nata de coco from coconut water. In addition, participants also received knowledge and skills on how to breed the starter nata de coco from the microorganism Acetobacter xylinum.

\section{Keywords: Training, Nata De Coco, Coconut Water, Acetobacter xylinum}

\section{PENDAHULUAN}

Pemanfaatan dari buah tanaman kelapa sangat beragam, buah kelapa dapat diolah menjadi bahan baku kopra, minyak kelapa, santan, kelapa parutan kering, minuman, bumbu masakan, dan nata de coco. Pengolahan air dari buah kelapa kurang maksimal dimanfaatkan oleh masyarakat di Desa Dunu Kecamatan Monano, Kabupaten Gorontalo Utara. Tanaman kelapa melimpah di Kecamatan Monano berdasarkan data BPS Kabupaten Gorontalo Utara (2019) bahwa di Kecamatan Monano Gorontalo Utara memiliki sekitar 749,50 ha luas perkebunan tanaman kelapa. Selain hanya dimanfaatkan sebagai minuman segar, air kelapa hanya dibuang begitu saja menjadi limbah. Masyarakat menggunakan daging kelapa menjadi beberapa olahan pangan namun menyisakan air kelapa yang harus dibuang menjadi limbah setiap harinya.

Pemanfaatn air kelapa dapat dilakukan salah satunya dengan membuat produk Nata de coco. Nata de coco merupakan turunan produk dari air kelapa dengan memanfaatkan mikroorganisme bakteri Acetobacter xylinum. Adanya gula sukrosa dalam air kelapa akan dimanfaatkan oleh Acetobacter xylinum sebagai sumber energi, maupun sumber karbon untuk menghasilkan senyawa metabolit di antaranya adalah selulosa yang menghasilkan Nata De Coco. Senyawa peningkat pertumbuhan mikroba (growth promoting factor) akan meningkatkan pertumbuhan mikroba, sedangkan adanya mineral dalam substrat akan membantu meningkatkan aktivitas enzim kinase dalam metabolisme di dalam sel Acetobacter xylinum untuk menghasilkan selulosa (Misgiyarta 2007 dalam Wirdhani 2018). Pembuatan nata de coco hanya menggunakan alat yang sederhana (Wijayanti, 2019) serta tidak memerlukan peralatan khusus, alat-alat rumah tangga yang umum tersedia di rumah dapat digunakan sehingga ibu-ibu pun tidak akan kesulitan dalam penyediaan alat untuk pembuatan nata (Nurdyansyah, 2017).

Menurut penelitian yang dilakukan oleh Puslitbang Biologi LIPI, kandungan gizi nata de coco per 100 gram nata mengandung $80 \%$ air, 20 gram karbohidrat, 146 kal kalori, 20 gram lemak, $12 \mathrm{mg}$ Kalsium, $2 \mathrm{mg}$ Fosfor dan 0,5 mg Ferrum (besi). Sedangkan kandungan gizi 100 gram nata de coco yang dikonsumsi dengan sirup adalah 67,7\% air, $12 \mathrm{mg}$ Kalsium, 0,2\% lemak, $2 \mathrm{mg}$ Fosfor (jumlah yang sama untuk vitamin B1 dan Protein), $5 \mathrm{mg}$ zat besi dan 0,01 ng (mikrogram) Riboflavin. Kandungan nutrisi dalam nata de coco tidak terlalu tinggi, terutama kalori. Maka, nata de coco baik untuk dikonsumsi oleh orang yang menjalani diet rendah kalori dan untuk penderita diabetes. Nata de coco kaya akan serat yang bermanfaat untuk melancarkan pencernaan (Rahayu, 2014)

Pembuatan nata de coco sangat mudah dan praktis serta dengan peralatan yang sederhana. Hal ini menjadi alasan penting agar hal ini mampu dilakukan oleh masyarakat di Desa Dunu Kecamatan Monano, Kabupate Gorontalo Utara dengan memanfaatkan air kelapa yang melimpah. Hal ini mampu meningkatkan pengetahuan dan softskill masyarakat untuk memaksimalkan pemanfaatan air kelapa. Selain itu hal ini mampu meningkatkan 
kemandirian dan peningkatan ekonomi masyarakat melalui pembuatan produk Nata de coco menggunakan mikroorganisme Acetobacter xylinum.

\section{SOLUSI DAN TARGET LUARAN}

\section{Solusi Permasalahan}

Beberapa hal dapat dilakukan dalam memanfaatkan limbah air kelapa yaitu salah satu diantaranya dengan membuat produk nata de coco berbahan dasar air kelapa dengan bantuan mikroorgaisme Acetobacter xylinum.

Melalui kegiatan pelatihan pembuatan nata de coco dengan memanfaatkan air kelapa di desa Dunu kecamatan Monano kabupaten Gorotalo utara menggunakan mikroorganisme Acetobacter xylinum diharapkan dapat dimanfaatkan sebaik-baiknya oleh masyarakat setempat dengan cara membentuk kelompok usaha kecil pengolahan air kelapa menjadi produk nata de coco.

Pembekalan dan pemberian materi mengenai jenis-jenis nata dan pembuatan nata de coco serta pembibitan starter Acetobacter xylinum sebagai mikroorganisme yang bisa digunakan dalam pembuatan nata juga akan diberikan sebagai bekal pengetahuan dalam pelatihan yang dilaksanakan di desa Dunu kecamatan Monano kabupaten Gorontalo Utara. Hal ini mampu memberikan manfaat kepada

\section{METODE PELAKSANAAN KEGIATAN}

Pada kegiatan pelaksanaan pelatihan ini akan didampingi langsung oleh tim Pelatihan yaitu 2 (dua) orang narasumber selama proses pendampingan saat pelatihan pembuatan nata de coco dari limbah air kelapa. Dapat diuraikan bahwa metode pelaksanan pelatihan adalah sebagai berikut:

- Kegiatan pelatihan diawali koordinasi dengan pemerintah setempat tentang masyarakat di desa Dunu kecamatan Monano kabupaten Gorontalo Utara yang memiliki kesadaran dalam mengelola usaha untuk memperoleh pendapatan yang layak serta meningkatnya jiwa kewirausahaan dan pengetahuan bagaimana mengembangkan pemanfaatan dari air kelapa.

\section{Luaran dan Target Capaian}

Adapun target luaran yang akan dicapai pada kegiatan Pelatihan ini adalah:

1. Menumbuhkan kesadaran, minat, pengetahuan dan keterampilan kepada masyarakat dalam memanfaatkan air kelapa yang melimpah.

2. Memanfaatkan air kelapa menjadi produk nata de coco yang bernilai ekonomis yang dapat menjadi peluang usaha masyarakat di Kabupaten Gorontalo Utara.

3. Mengembangkan pengetahuan dan keterampilan yang diperoleh dengan mengkolaborasikan dari sumbersumber bacaan, baik melalui buku, hasil penelitian, ataupun dari media-media sosial.

4. Meningkatkan kesadaran masyarakat Kabupaten Gorontalo Utara dalam mengelola usaha untuk memperoleh pendapatan yang layak serta meningkatkan jiwa kewirausahaan dan pengetahuan masyarakat Kabupaten Gorontalo Utara dalam mengembangkan pemanfaatan air kelapa yang melimpah.

waktu yang tepat untuk melaksanakan kegiatan Pelatihan

- Tim menyediakan alat dan bahan yang akan digunakan dalam proses pelatihan pembuatan nata de coco.

- pelatihan dilaksanakan pada hari ahad tanggal 20 September 2020

- Pelatihan pertama-tama diawali dengan pemberian materi dari narasumber mengenai prosedur dan cara pembuatan nata de coco dari air kelapa serta cara melakukan pembibitan starter Acetobacter xylinum sebagai salah satu 
bahan utama dalam pembuatan nata de coco.

- Pelatihan kedua yakni praktek langsung pembuatan nata de coco dari air kelapa dan melakukan praktek pembibitan starter Acetobacter xylinum.

Kegiatan ini nantinya tim Pengabdian/Pelatihan akan terus menjalin komunikasi dengan pihak mitra tentang pembuatan nata de coco dan pembibitan starter nata de coco menggunakan air kelapa dengan menggunakan bakteri Acetobacter xylinum dan permasalahan lainnya yang menjadi kendala di kecamatan tersebut. Lokasi pengabdian akan menjadi desa binaan terutama dalam hal pembuatan nata de coco. Sehingga komunikasi akan terus dilaksanakan untuk pengembangan program kedepannya.

\section{HASIL DAN PEMBAHASAN}

Hasil dari pelaksanaan Pelatihan pembuatan nata de coco dari limbah air kelapa di desa Dunu, Kecamatan Monano Kabupaten Gorontalo Utara adalah sebagai berikut:

1. Jumlah peserta mencapai 65 orang yang terdiri dari ibu-ibu rumah tangga, pemuda(i) desa dan beberapa orang aparat desa

2. Peserta Pelatihan yang terdiri dari ibuibu rumah tangga memberikan respon yang sangat baik dan mereka sangat tertarik serta antusias dengan materi yang disampaikan. Karena alat yang digunakan dalam pembuatan nata de coco serta pembibitan starter nata de coco menggunakan bakteri Acetobacter xylinum merupakan alat yang sederhana dan dapat ditemukan di rumah tangga sehingga pembuatannya sangat udah untuk dilaksakan oleh peserta.

Pembuatan nata de coco sangat menarik bagi peserta karena cara pembuatan nata de coco yang sangat mudah dengan bahan dan alat yang mudah didapatkan serta mampu mengatasi masalah lingkungan limbah air kelapa.

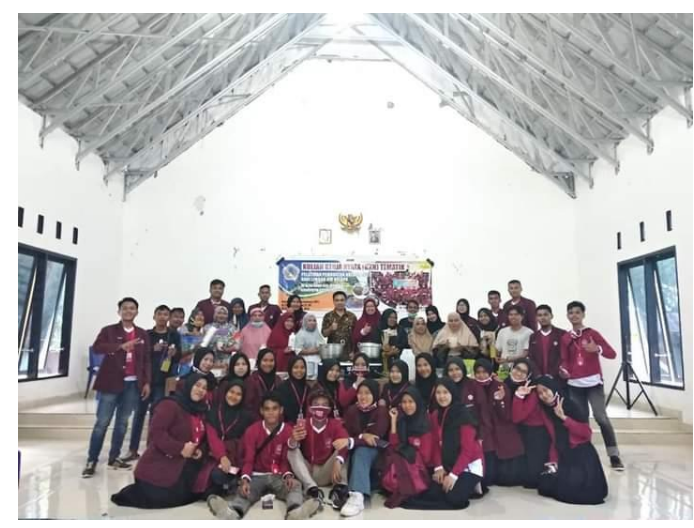

Gambar 1. Kegiatan pelatihan pembuatan nata de coco dari limbah air kelapa

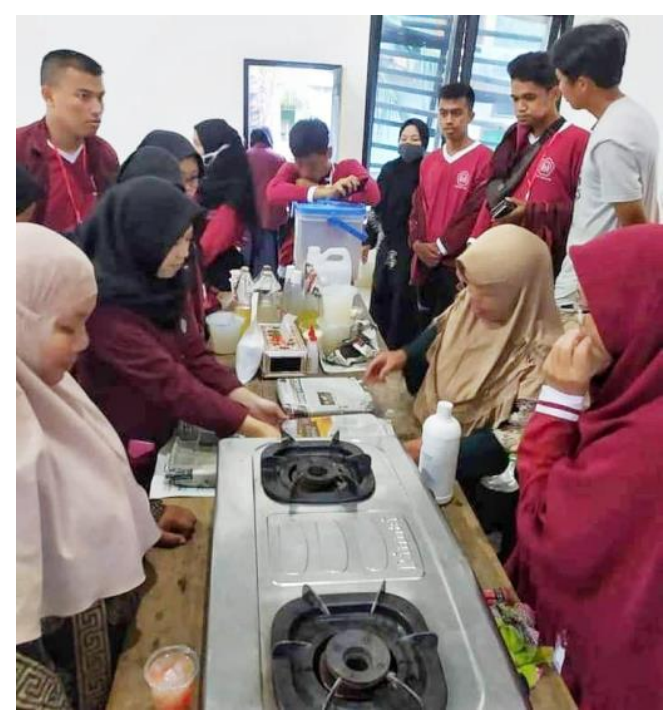

Gambar 2. Antusiasme masyarakat terhadap kegiatan pelatihan pembuatan nata de coco dari limbah air kelapa

Pelatihan pembuatan nata de coco dari limbah air kelapa di desa Dunu didukung oleh masyarakat, ditandai dengan peran aktif dari Karang Taruna desa Dunu, mulai dari perencanaan sampai dengan pelaksanaan kegiatan pelatihan. Kegiatan pelatihan dihadiri oleh ketua Karang Taruna yang memberikan tanggapan bahwa pelatihan pembuatan Nata De Coco dari Limbah Air Kelapa dapat dijadikan salah satu program kegiatan BUMDES Desa Dunu.

Kegiatan pelatihan pembuatan nata de coco dari limbah air kelapa di desa Dunu berjalan dengan baik dan lancar serta 
memberikan kontribusi kepada peserta yaitu pengetahuan dan skill mengenai prosedur dan cara pembuatan nata de coco dari air kelapa serta cara melakukan pembibitan starter Acetobacter xylinum sebagai salah satu bahan utama dalam pembuatan nata de coco.

\section{KESIMPULAN DAN SARAN}

Masyarakat Desa Dunu lebih terampil dalam membuat nata de coco dari limbah air kelapa, yang ditandai dengan hasil yang dibuat dari kegiatan inti berupa produk nata de coco. Hasil dari Program kegiatan inti tercapai dalam aspek menciptakan produk bernilai konsumtif dan ekonomis. Kegiatan pelatihan pembuatan nata de coco dari limbah air kelapa, didukung oleh pemuda Karang Taruna menjadi salah satu BUMDES Desa Dunu.

\section{UCAPAN TERIMAKASIH}

Penulis mengucapkan terima kasih kepada Ibu Dr. Hariana, S.Pd., M.Ds., Bapak Sirus A. Manggabai selaku Kepala Desa Dunu, Bapak Agusrianto S. Ogu selaku Sekretaris Desa Dunu dan Karang Taruna Desa Dunu serta masyarakat desa Dunu atas partisipasi dan dukungannya dalam pelaksanaan kegiatan ini. Sehingga kegiatan ini dapat terlaksana dengan baik dan lancar.

\section{DAFTAR PUSTAKA}

BPS Kabupaten Gorontalo Utara. 2019. Kabupaten Gorontalo Utara Dalam Angka

2019.https://gorontaloutarakab.bps.go. id/publication/download.html?nrbvfev e=ZmZjMjkxZTg3MGYxN2ZmZTM xNjhiYjk1\&xzmn=aHR0cHM6Ly9nb 3JvbnRhbG91dGFyYWthYi5icHMuZ 28uaWQvcHVibGljYXRpb24vMjAx OS8wOC8xNi9mZmMyOTFIODcwZj E3ZmZlMzE2OGJiOTUva2FidXBhd GVuLWdvem9udGFsby11dGFyYS1k YWxhbS1hbmdrYS0yMDE5Lmh0b Ww\%3D\&twoadfnoarfeauf=MjAyMC
0wOS0zMCAxMjowMDoyOQ\%3D\% 3D. Katalog 1102001.7505

Nurdyansyah Fafa dan Ayu Widyastuti. 2017. Pengolahan Limbah Air Kelapa Menjadi Nata De Coco Oleh Ibu Kelompok Tani Di Kabupaten Kudus. JKB Vol. 21. No.XI. ISSN : 1979-861X e-ISSN : 2549-1555 22 Desember 2017. Pendidikan Biologi, Universitas PGRI Semarang.

Rahayu dkk. 2014. Aspek Mutu Produk Nata De Coco Dengan Penambahan Sari Buah Mangga. Jurnal Teknik Industri HEURISTIC Vol. 11 No. 2 Oktober 2014. ISSN 1693-8232 63 UNTAG Surabaya. *Corresponding author: rinisihmawati@yahoo.com

Whirdani Lubis dan Nirwana Harahap. 2018. Pemanfaatan Sari Buah Naga Super Merah (Hylocereus Costaricensis) Pada Pembuatan Nata De Coco Terhadap Mutu Fisik Nata Utilization Of Super Red Dragon Fruit (Hylocereus Costaricensis) In The Making Of Nata De Coco Against Nata Physical Qualitycheds. Journal of Chemistry, Education, and Science Vol. 2 No. 2, Desember 2018 Universitas Islam Sumatera Utara, Indonesia *Corresponding author: wirdhani_dila@fkip.uisu.ac.id

Wijayanti Erna. 2019. Peningkatan Ekonomi Masyarakat Melalui Home Industry Nata De Coco Berbasis Potensi Lokal. DIMAS - Volume 19, Nomor 1, Mei 2019. Islam Negeri Walisongo, Semarang. 